\title{
Climate Change and Its Impact on Food Security
}

\author{
Aman Mann \\ Assistant Professor, Department of Environmental Science, CMK National PG Girls College Sirsa 125055 \\ DOI: 10.29322/IJSRP.11.12.2021.p12063 \\ http://dx.doi.org/10.29322/IJSRP.11.12.2021.p12063
}

\begin{abstract}
Climate change is posing a serious threat to humanity, as the world's population grows the demand for food and water will also increase. The rise in global surface temperatures is a big challenge for Food security. The rise in temperature will cause water shortage. Haryana is primarily an Agriculture state and stands second at food production in India. Climate change in Haryana will lead to reduced crop yield henceforth a threat to Nations food basket. Rise in temperature will impact all the crops, for every degree rise in temperature there is a significant decline in the yield of Wheat. A reduced rainfall will impact both Kharif (Summer) and Rabi (Winter) crops. The rise in Global surface temperature is primarily due to the release of Green house gases to the atmosphere. Rapid Industrialization and increase in population is laying stress on our resources.

The change in Agriculture practices as well as the change in consumption patterns is also responsible for the long term change in climate. Change in consumption patterns alone cannot combat the challenge of food security; new technologies have to be adopted rapidly to meet the ever growing needs of Food and Water.
\end{abstract}

Index Terms- Climate Change, Rise in Temperature, Decline in Yield, Food Security, Green House Gases, Increased Winter Temperature.

\section{INTRODUCTION}

$\mathrm{C}$ limate change is a change in the usual weather found in a place; this could be a change in annual rainfall or a change in usual temperature for a month or season (NASA). Climate change is a threat to Food security as changes in temperature and precipitation threaten agricultural productivity and the capacity to feed the world's ever growing population. The changing climate will influence the crop pattern of a region.

Ground water for global water and food security will probably intensify under climate change as more frequent and intense climate extremes (droughts and floods) increase variability in precipitation, soil moisture and surface water.- (Nature Climate change 2013).

This review article is about Climate change in Haryana state of North India and specifically of its Sirsa district.

Sirsa is the North western most district of Haryana State with a geographical area of $4270 \mathrm{sq} . \mathrm{Km}$ located between $29^{\circ} 13^{\prime}$ $: 29^{\circ} 59^{\prime} \mathrm{N}$ Latitudes and $74^{\circ} 30^{\prime}: 75^{\circ} 7^{\prime} \mathrm{E}$ Longitude. The climate of Sirsa district is tropical desert type. The climate of the area is characterized by its dryness, extremes of temperature and scanty rainfall. The mean daily maximum temperature during May and June, which is the hottest period, varies from 41 to $46^{\circ} \mathrm{C}$. There is no Meteorological observatory in the district; hence the mean meteorological conditions observed in the surrounding districts may be taken as representatives of the district (India Census, 2011)

This region in Haryana was Arid before the 1980s from the 1980s it started turning semi arid the humidity increased and an increase in annual rainfall was observed. This led to changing the sand dunes to plain lands and is being used as land for cultivating crops. The crop pattern changed from crops like Maize Barley to Rice cultivation. From the 1990s the water table started going down and from the beginning of the new millennia that is year 2000 the water table started going down more rapidly every year the water level goes down by almost 10 Feet .and the wells have to be dugged deeper every year.

A Survey by the central soil salinity research institute (CSSRI) reported 48,098 hectares in state have turned barren and saline due to shallow water table less than 1.5 meters. Most of the water logged soils occur in arid and semi arid regions of the state including Sirsa district where 2325 hectares land turned barren due to shallow water table below 1.5 meters.

Recent data gathered by the Ground water wing of Agriculture department of Haryana State revealed that most districts in the state have witnessed a critical fall of $7.29 \mathrm{~m}$ on an average in the past 12 years.

Society for Conservation of natural resources and empowerment of rural youth said that the ground water levels are falling rapidly by almost a meter every year in these semi arid regions.

The state is among the most exploited regions in the world for groundwater. Deficient rains add another dimension to the crisis. The state had been getting below par rainfall for the past 16 years. Prof Krishna Achuta Rao from IIT Delhi's Centre for Atmospheric Sciences plotted the annual and seasonal rainfall for the state since 1980. The rain stats were obtained from the India Meteorological Department. The linear graph reveals a trend of decreasing rains. It shows average annual rainfall in Punjab falling during this period from just over $780 \mathrm{~mm}$ in 1980 to less than 580 $\mathrm{mm}$ in 2014 - a drop of roughly $200 \mathrm{~mm}$. The Annual rainfall dropped down to $384 \mathrm{~mm}$ in 2017 which is a further drop of $200 \mathrm{~mm}$. The situation is alarming; farmers now draw more groundwater to irrigate their crops, particularly paddy, accelerating the fall of the water table. Less rain means lesser ground water availability as the ground water mainly depends on the rainfall for recharge; Sirsa shows decreasing trend in the monsoon rainfall.

Haryana is primarily an agricultural state. About $70 \%$ of residents are engaged in agriculture. Haryana is at Second position in food grain production in the country. 
The long term analysis for trends in observed temperature over Haryana using IMD gridded temperature at daily time scales show that there is no significant trend in the mean maximum temperature while the mean minimum temperature shows an Increase of about $1.0^{\circ} \mathrm{C}$ to $1.2^{\circ} \mathrm{C}$.

Maximum temperature of Sirsa in all the months in winter has decreased from normal. Annual mean maximum temperature also decreased by $0.2^{\circ} \mathrm{C}$ during the period $1995-2014$ from normal of $31.5^{\circ} \mathrm{C}$, whereas, mean minimum temperature in all months had increased from normal with annual increase of $0.14^{\circ} \mathrm{C}$ during the period 1995-2014. Rainfall in the region had shown a bit increase from normal during recent past.

\section{REASONS FOR CLIMATE CHANGE}

Rise in global temperature is largely due to increased concentrations of greenhouse gases, which include carbon dioxide $\left(\mathrm{CO}_{2}\right)$, methane $\left(\mathrm{CH}_{4}\right)$, nitrous oxide $\left(\mathrm{N}_{2} \mathrm{O}\right)$ and Chlorofluorocarbons (CFCs).

Climate change and climate variability will have major implications for water availability, forest cover, biodiversity, crop production, and food security. Changes in rainfall pattern are of greater importance for agriculture than the annual changes in temperature, especially in regions where lack of rainfall may be a limiting factor for crop production. Haryana emits nearly $2 \%$ of national greenhouse gases (GHG). Agriculture sector contributes about $82 \%$ and $91 \%$ of $\mathrm{CH} 4$ and $\mathrm{N} 2 \mathrm{O}$ emissions of the state. Majority of $\mathrm{CH} 4$ emissions occur from enteric fermentation of livestock (62\%) followed by rice cultivation (14\%) and biomass burning (6\%). While majority of $\mathrm{N} 2 \mathrm{O}$ emissions occur from application of synthetic nitrogenous fertilizer $(62 \%)$ followed by indirect $\mathrm{N} 2 \mathrm{O}$ emissions (20\%) and nitrogen from crop residue left $(5 \%)$.
Sirsa and Hisar are the highest $\mathrm{N}_{2} \mathrm{O}$ emitting districts contributing about $11 \%, 9 \%$ and $8 \%$ of the state $\mathrm{N}_{2} \mathrm{O}$ emissions respectively. Synthetic nitrogen application is the main $\mathrm{N}_{2} \mathrm{O}$ emissions source in these districts.

\section{IMPACT OF THE CLIMATE CHANGE ON CROP PRODUCTIVITY OF THIS REGION}

Haryana is self sufficient in food production and the second largest contributor to India's central pool of food grains.

The water limitation is key to food security and is normally the rate-limiting factor for plant growth at lower latitudes (Churkina \& Running, 1998)

S.K. Sinha and M. S. Swaminathan (1991) analyzed that a $2^{\circ} \mathrm{C}$ increase in mean air temperature could decrease rice yield by about 0.75 ton/hectare and $0.5^{\circ} \mathrm{C}$ increase in winter temperature would reduce wheat crop duration by seven days and reduce yield by 0.45 ton/hectare. An increase in winter temperature of $0.5^{\circ} \mathrm{C}$ would thereby translate into a 10 percent reduction in wheat production in the high yield states of Punjab, Haryana and Uttar Pradesh.

My Grandfather told me that back in the early 80s this place was more like a desert very frequent dust storms and a lower frequency of rains.

The minimum temperature increased by $1^{\circ} \mathrm{C}$ to $1.3^{\circ} \mathrm{C}$ in the Districts of Fatehabad, Jhajjar and Karnal which is higher than the other parts of the Haryana.

Observations by the Indian Meteorological department (IMD) of the Trends and patterns of Rainfall and Temperature for about past Ten years (2005-2014) is reflecting how the climate changed Increase in temperature also causes reduction in rainfall in the arid plains and the reduction in rainfall and rise in temperatures will reduce the agricultural productivity.

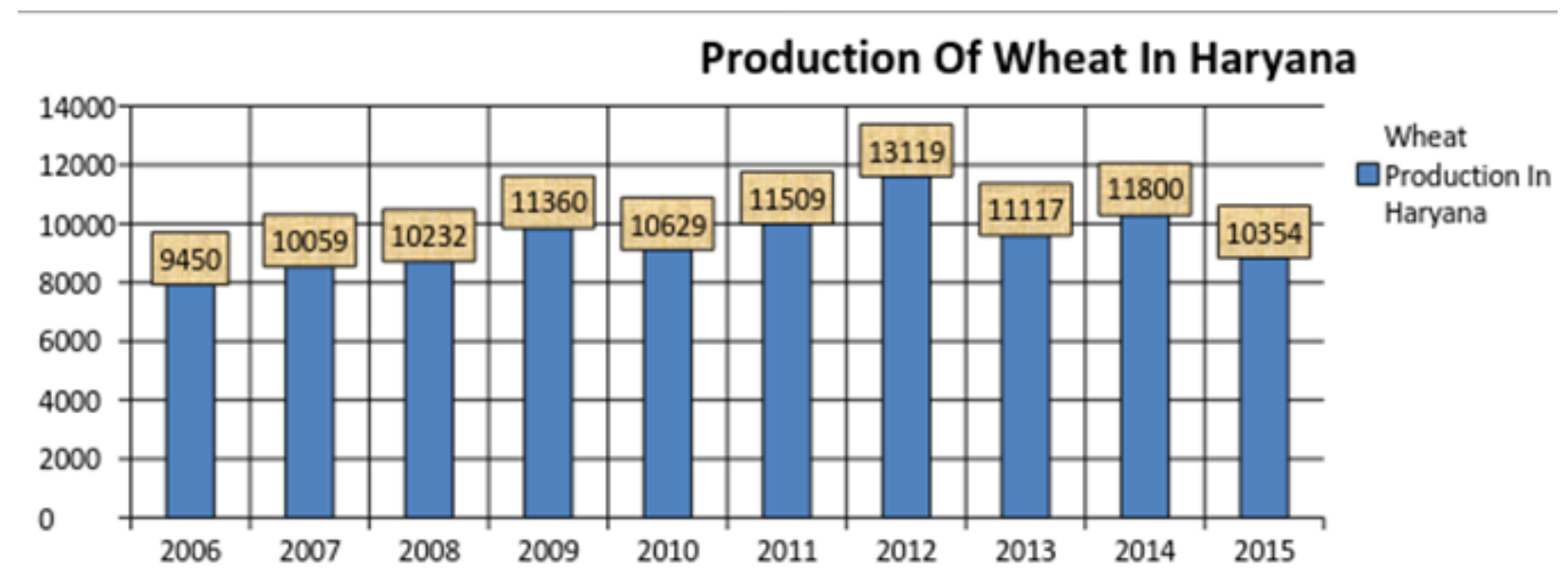

(International Journal of Academic Research and Development, volume 2 issue 5, 2017)

The trend in the above data shows that the wheat production in Haryana was highest in 2012 in the other years there was no fixed trend it shows decreasing as well as increasing trends this may be due to change in temperature and variations in number of Winter days.
The changes in these weather elements over long period can be considered as regional/local effect of changing climate at global level. 
Increased temperature will increase Evapo-transpiration that will have an adverse impact on surface runoff which will affect the canal water availability.

\section{IMPACT OF CLIMATE CHANGE ON RICE CROP}

Aggarwal et al. (2000) mention potential rice productions of $10.8103 \mathrm{~kg}$. ha-1 for Sirsa. However, 2002 was a year with relatively high temperatures and a shorter growing season, resulting in relatively low productions. In years with a lower average day temperature, the growing season was a little longer (crop development is determined by temperature, TSUMs). As a result of climate change temperatures are expected to increase. The rise in atmospheric temperature causes detrimental effects on growth, yield, and quality of the rice crop by affecting its phenology, physiology, and yield components (Singh 2001, Sheehy et al. 2005, Peng et al. 2004).

\section{CONCLUSION AND SUGGESTIONS}

The rise in global surface temperature and water scarcity due to climate change is posing a threat to our Food security as it estimated that the Crop yields might decrease as a consequence of Climate change. Precision Agriculture, Climate smart agriculture as well Advances in Agriculture technology could be a sustainable way to achieve the target of Food Security. Good seed varieties is one of them, Indian Institute of Rice Research (IIIR) announced the development of a new high zinc variety of rice, which requires less water and reduces input costs. This new Rice variety can help farmers grow rice sustainably in the shallow water zones If current trends in Climate change persist until 2050, major crop yields and the food production capacity of Asia will decrease significantly. In response to this situation, CIMMYT and partners are developing heat stress-resilient maize for Asia. Similarly if the world gets a heat resilient Wheat variety we will be able to save our Bread basket which is being impacted by the rise in temperature due to Climate change. The consumptions patterns alone cannot help achieve Food security alone, new technology and precision have to come along with to feed the ever growing population.

\section{REFERENCES}

[1] Agricultural Water Management, Sinha SK, Swaminathan MS, 1991; 69(1):1-11.

[2] Sheehy, J.E., Elmido, A., Centeno, G. and Pablico, P. 2005. Searching for new plant for climate change. Journal of Agricultural Meteorology 60:463468

[3] Singh, S. 2001. Growth, yield and biochemical response of rice genotype to low light and high temperature-humidity stress. Oryza 37 (1):35-38

[4] Aggarwal, P.K., R.P. Roeter, N. Kalra, H. Van Keulen, C.T. Hoanh and H.H Van Laar (Eds.), 2001. Land use analysis and planning for sustainable food security: with an illustration for the state of Haryana, India. New Delhi, Indian Research Institute/Los Baños, International Rice Research Institute/Wageningen, Wageningen University and Research Center. $167 \mathrm{pp}$

[5] Ground Water Information Booklet of Sirsa District Haryana, Central Ground Water Board, Ministry of Water Resources

[6] 16 year poor monsoon in Punjab and Haryana TOI News

[7] https://timesofindia.indiatimes.com/india/16-year-trend-of-poor-monsoonin-Punjab-Haryana/articleshow/43115393.cms?from=mdr 1/40

[8] Airon, Anurag \& Kumar, Anil \& Singh, Diwan \& Singh, Raj \& Kumar, Manoj \& Singh, Surender. (2017). Local impact of climate change: A case study of western Haryana, India. . 10.13140/RG.2.2.12290.99527.

[9] Haryana State Action Plan on Climate change, Government of Haryana

\section{AUTHORS}

First Author - Aman Mann, Assistant Professor, Department of Environmental Science, CMK National PG Girls College Sirsa 125055 